
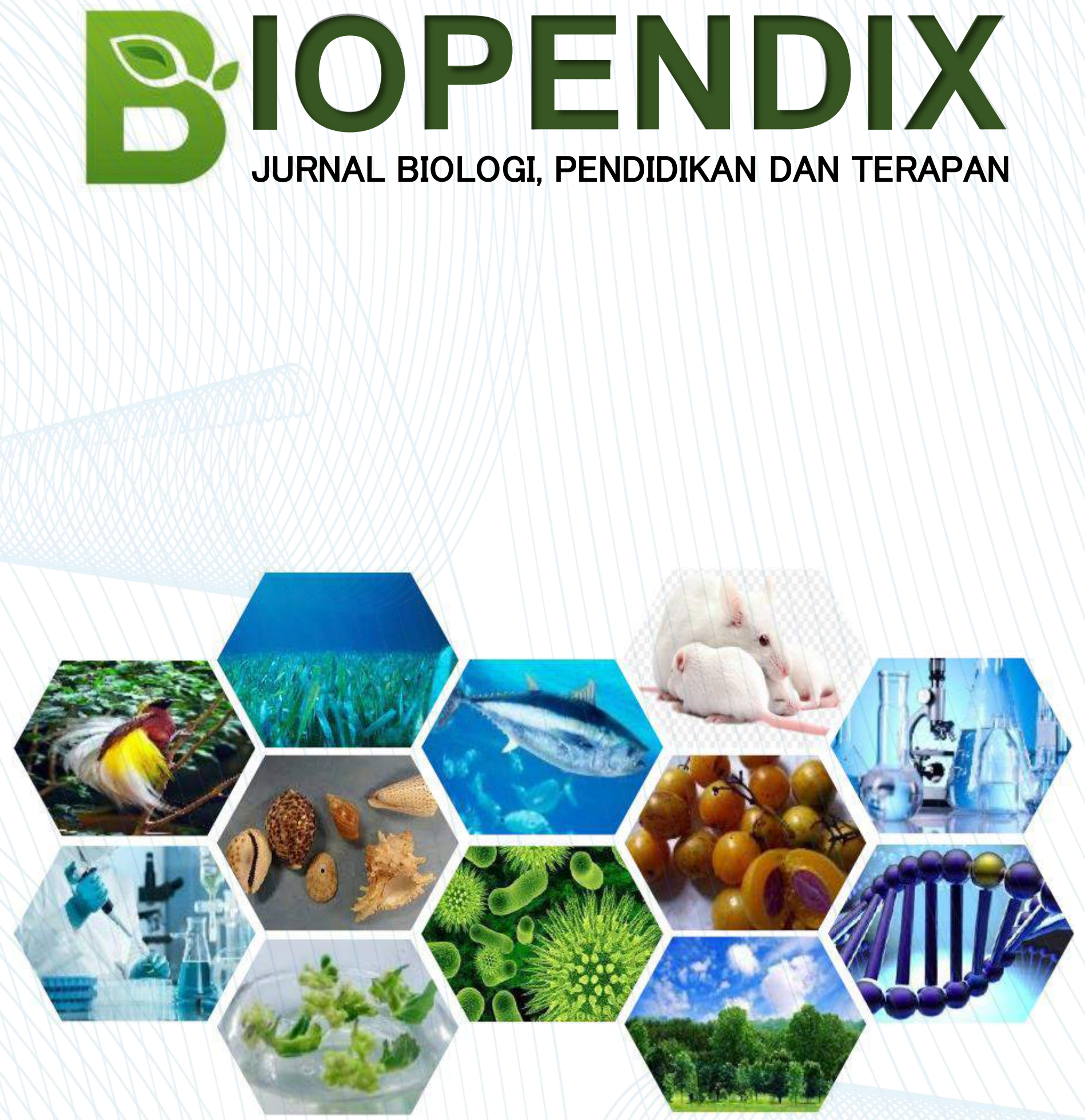

PUBLISHER BY:

BIOLOGY EDUCATION, UNPATTI AMBON - MALUKU 


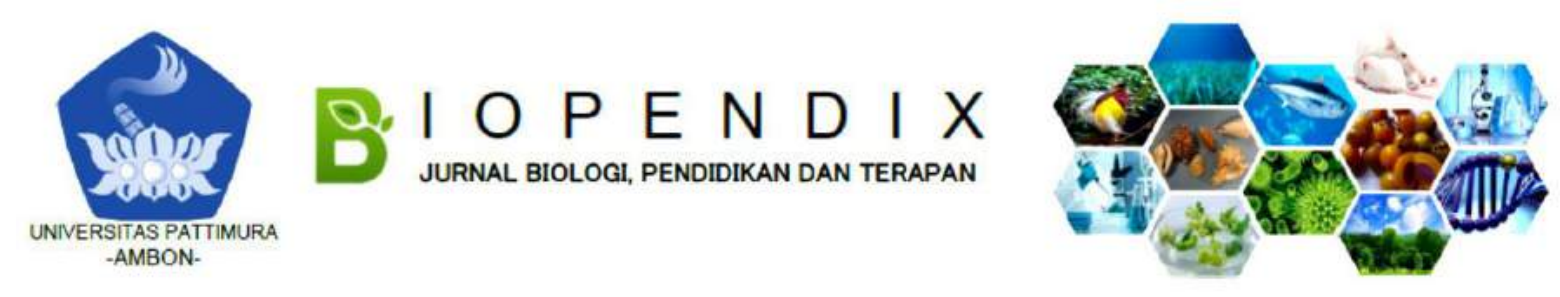

\title{
UPAYA PENINGKATAN HASIL BELAJAR BIOLOGI MELALUI MODEL PEMBELAJARAN SIMAS ERIC PADA SISWA SMP NEGERI SATU ATAP KAIRATU KABUPATEN MALUKU TENGAH
}

\author{
Mychael Pentury ${ }^{1}$, P. M. J. Tuapattinaya ${ }^{\star 2}$, S. I. A. Salmanu² \\ ${ }^{1}$ Alumni Program Studi Pendidikan Biologi; ${ }^{2}$ Program Studi Pendidikan Biologi
}

*Corresponding author: P.M.J. Tuapattinaya; e-mail: pmjtuapattinaya.unpatti@gmail.com

\begin{abstract}
Background: The use of appropriate learning models, is an alternative to overcome the problem of students' low absorption of lessons, in order to improve the quality of teaching. SIMAS ERIC learning model (Skimming, Mind Mapping, Questioning, Exploring, Writing, and Communicating) is a learning model that helps teachers train students to plan learning, monitor the learning process, and evaluate student learning outcomes. This study aims to determine the implementation of SIMAS ERIC (Skimming, Mind Mapping, Questioning, Exploring, Writing, and Communicating) learning models to improve biology learning outcomes in eighth grade students of one-roof state junior high school, Kairatu.

Method: The research design used was descriptive research. Research subjects were 25 garde VIII students. Data on biology learning outcomes are obtained through pre-test and post-test, observation to observe cognitive, affective, and psychomotor abilities.

Results: The average achievement score obtained at the final value is $85.23 \%$.

Conclusion: There is an increase in student learning outcomes shown through the results of formative tests after being taught breathing system material in human beings with the application of the SIMAS ERIC learning model (Skimming, Mind mapping, Questioning, Exploring, Writing, Communicating)
\end{abstract}

Keywords: SIMAS ERIC Learning Model, Learning Outcomes.

\begin{abstract}
Abstrak
Latar Belakang: Penggunaan model pembelajaran yang tepat, merupakan alternatif untuk mengatasi masalah rendahnya penyerapan siswa terhadap pelajaran, dalam rangka meningkatkan kualitas pengajaran. Model pembelajaran SIMAS ERIC (Skimming, Mind Mapping, Questioning, Exploring, Writing, and Communicating) adalah model pembelajaran yang membantu guru melatih siswa untuk melakukan perencanaan pembelajaran, memantau proses pembelajaran, dan mengevaluasi hasil belajar siswa. Penelitian ini bertujuan untuk mengetahui implementasi pembelajaran model SIMAS ERIC (Skimming, Mind Mapping, Questioning, Exploring, Writing, Communicating) untuk meningkatkan hasil belajar biologi pada siswa kelas VIII SMP Negeri satu atap, Kairatu.

Metode: Desain penelitian yang digunakan adalah penelitian deskriptif. Subjek penelitian adalah 25 siswa garde VIII. Data hasil belajar biologi diperoleh melalui pre test dan post test, observasi untuk mengamati aspek kognitif, afektif, dan kemampuan psikomotorik.

Hasil: Diperoleh skor prestasi rata-rata pada nilai akhir yaitu, sebesar $85,23 \%$.

Kesimpulan: Ada peningkatan hasil belajar siswa ditunjukan lewat hasil tes formatif setelah diajarkan materi sistem pernapasan pada manuisa dengan penerapan model pembelajaran SIMAS ERIC (Skimming, Mind mapping, Questioning, Exploring, Writing, Communicating)
\end{abstract}

Kata Kunci: Model Pembelajaran SIMAS ERIC, Hasil belajar. 


\section{PENDAHULUAN}

Pendidikan merupakan suatu modal besar suatu bangsa untuk bias berkembang dan maju. Pendidikan diarahkan untuk mengatasi permasalahan bangsa selama ini, maka diperlukan produk pendidikan yang memadai bukan hanya dari segi komunitas, tapi juga dari segi kualitas. Kualitas pendidikan ditentukan oleh kualitas lulusan dari suatu institusi pendididkan (Paramitha, 2011). Pembelajaran biologi sudah dilaksanakan mulai dari jenjang SD dan SMP dalam mata pelajaran IPA. Pembelajaran biologi meliputi produk, proses, aplikasi/teknologi, dan nilai dalam aspek-aspek kehidupan makhluk hidup. Sedangkan pola yang digunakan dalam Pembelajaran Biologi dapat berupa pola deduktif maupun induktif yang keduanya bertujuan untuk mempermudah siswa mencapai hasil belajar yang telah ditargetkan Corebima, 2009).

Biologi sebagai ilmu memiliki kekhasan tersendiri dibandingkan dengan ilmu-ilmu yang lain. Biologi merupakan salah satu ilmu pengetahuan yang mempelajari makhluk hidup dan kehidupannya dari berbagai aspek persoalan dan tingkat organisasinya. Produk keilmuan biologi berwujud kumpulan fakta-fakta maupun konsep-konsep sebagai hasil dari proses keilmuan biologi (Sudjoko, 2001). Pembelajaran Biologi saat ini mengalami kendala, diantaranya adalah model pembelajaran yang kurang cocok, penggunaan media yang kurang tepat, kondisi kelas yang selalu pasif, termasuk juga kurangnya guru memperhatikan keadaan dan minat siswa dalam kelas. Selain itu, biologi juga juga sering dikatakan sebagai bidang studi yang membosankan dan tidak disukai siswa. Hal ini tampak dari perilaku siswa yang menunjukkan sikap tidak tertarik pada saat mengikuti pelajaran biologi, misalnya banyak yang berbicara sendiri, siswa sering keluar masuk kelas, kelas menjadi ramai ketika guru menyampaikan materi, dan lain-lain.

Hasil belajar adalah kemampuan yang dimiliki peserta didik setelah menerima pengalaman belajar (Sudjana, 2010). Hasil belajar kognitif merupakan salah satu tolak ukur keberhasilan peserta didik dalam mencapai kompetensi yang telah ditentukan oleh kurikulum. Hasil belajar kognitif peserta didik berkaitan dengan beberapa faktor yang berasal dari dalam (internal) dan dari luar (eksternal) peserta didik. Beberapa faktor internal yang mempengaruhi hasil belajar peserta didik meliputi tingkat kecerdasan, bakat, minat, motivasi, sikap, perasaan dan emosi. Faktor eskternal yang berkaitan dengan hasil belajar peserta didik berupa bahan pelajaran, metode pengajar, metode pendidikan, keadaan keluarga dan situasi lingkungan sekitarnya (Suprijono, 2011).

SIMAS ERIC (Skimming, Mind mapping, Questioning, Exploring, Writing, and Communicating) merupakan salah satu model pembelajaran yang dapat membantu guru untuk melatih siswa melakukan perencanaan belajar, memonitor proses belajar, dan mengevaluasi hasil belajarnya. Darmawan dkk (2014) menjelaskan tahapan model pembelajaran SIMAS ERIC: (1) Skimming: melakukan survei dengan cepat pada setiap bab, (2) Mind mApping: membuat peta pikiran dari bab yang diskimming, (3) QueStioning: mengajukan pertanyaan tingkat tinggi (why and how), (4) Exploring: menelaah materi kembali untuk menjawab pertanyaan, (5) WRIting: menuliskan jawaban pertanyaan secara ringkas, dan (6) Communicating: mengkomunikasikan secara kolaboratif hasil mindmap, pertanyaan dan jawabannya.

Berdasarkan hasil observasi dan wawancara di kelas VIII SMP Negeri 1 Atap Kairatu Di Hatusua menunjukan hasil belajar dari 25 peserta didik kurang dari Kriteria Ketuntasan Minimal (KKM) dan sebagian besar siswa mengisi waktu luang dengan aktivitas di luar membaca buku, misalnya menonton TV dan bermain gadget oleh karena itu, hasil belajar siswa rendah. $\mathrm{Hal}$ ini dapat terlihat selama proses belajar mengajar berlangsung, dimana hanya sebagian siswa yang memperhatikan penjelasan dan membuat ringkasan materi yang disampaikan oleh guru yang bersangkutan. Siswa juga terlihat pasif selama proses pembelajaran berlangsung, sehingga interaksi antara guru dan siswa juga sangat rendah.

Berdasarkan latar belakang di atas, maka peneliti berupaya untuk meningkatkan 
hasil belajar Biologi siswa dengan cara menerapkan model pembelajaran SIMAS ERIC (Skimming, Mind mapping, Questioning, Exploring, Writing, Communicating) bagi siswa kelas VIII SMP Negeri Satu Atap Kairatu Di Hatusua.

\section{METODE}

Subjek dalam penelitian ini adalah siswa kelas VIII dengan jumlah siswa sebanyak 25 orang. Teknik Pengumpulan data dalam penelitian ini terdiri atas dua, yaitu teknik tes $\mathrm{n}$ teknik non tes. Tes yang diberikan pada awal dan akhir pembelajaran dan bertujuan untuk mengetahui tingkat pemahaman siswa terhadap materi sistem ekskresi pada manusia. Teknik non tes berupa lembar penilaian afektif, lembar penilaian psikomotor.

Data dalam penelitian ini diolah menggunakan analisis statistic deskriptif. Analisis deskriptif dilakukan dengan langkah-langkah sebagai berikut, skor pencapaian (SP) atau Nilai (N) hasil tes awal, tes akhir kemampuan afektif tiap tatap muka, kemampuan psikomotor, kemampuan kognitif tiap tatap muka, dan kemampuan kognitif tiap LKS (Arikunto, 2005) diperoleh dengan cara:

$\mathrm{SP}=\frac{\text { Skor pencapaian }}{\text { Skor maksimum }} x 100$

Selanjutnya Nilai proses (NP) diperoleh dengan cara :

$\mathrm{NP} \frac{\text { Nilai Kognitif }+ \text { Nilai Afektif }+ \text { Nilai Psikomotor }}{3}$

Setelah memperoleh nilai dari tiap aspek, maka selanjutnya nilai tersebut dihitung untuk memperoleh nilai akhir, rumusnya:

$\mathrm{NA}=\frac{6 P+4 P}{10}$

Keterangan :

NA : Nilai Akhir

$\mathrm{P}$ : Nilai Proses

Nilai hasil tes formatif setelah proses pembelajaran

\section{HASIL DAN PEMBAHASAN}

\section{a. Hasil}

\section{Penyajian Data}

\section{1) Deskripsi Kemampuan Awal Siswa (Pre-test)}

Tes awal adalah kegiatan yang dilakukan sebelum proses belajar mengajar di mulai yang bertujuan untuk mengetahui sejauh mana pemahaman siswa mengenai konsep yang akan diajarkan yaitu sistem pernapasan pada manusia. Hasil tes awal menggambarkan kemampuan awal siswa sebelum mengikuti proses kegiatan belajar mengajar (KBM) materi sistem pernapasan pada manusia dengan menerapkan model pembelajaran SIMAS ERIC (Skimming, Mind mapping, Questioning, Exploring, Writing, Communicating). Kualifikasi presentase pencapaian hasil tes awal siswa dapat dilihat pada tabel berikut.

\section{Tabel 1. Kualifikasi Tingkat Penguasaan} Siswa Pada Tes Awal

\begin{tabular}{clll}
\hline Interval & Frekuensi & $(\%)$ & Kualifikasi \\
\hline$\geq 75$ & - & - & Tuntas \\
$\leq 75$ & 25 & 100 & Gagal \\
Jumlah & 25 & 100 & - \\
\hline
\end{tabular}

Dari tabel di atas terlihat hasil pencapaian siswa pada tes awal, dimana pada interval $\geq 75$ belum ada siswa yang mencapai kualifikasi tuntas dan pada interval $\leq 75$ terdapat 25 siswa (100\%) dengan kualifikasi gagal yang belum mampu menguasai indikator-indikator pembelajaran yang akan dipelajari. Sehingga dapat dikatakan ketuntasan belajar siswa belum tercapai dengan skor rata-rata pencapaian $39,6 \%$.

\section{2) Deskripsi Kemampuan Siswa Selama Proses Pembelajaran}

Hasil belajar siswa dalam kegiatan proses belajar mengajar dengan menerapkan model pembelajaran SIMAS ERIC (Skimming, Mind mapping, Questioning, Exploring, Writing, Communicating) dinilai berdasarkan 3 aspek yaitu aspek kognitif, aspek afektif dan aspek psikomotor. 


\section{Data kemampuan kognitif siswa}

Berdasarkan hasil penelitian yang dilakukan pada SMP Negeri 1 Atap Kairatu di Hatusua, kemampuan kognitif siswa dalam proses pembelajaran dalam hal ini siswa mengerjakan lembar kerja siswa (LKS) selama tiga pertemuan. Siswa dibagi menjadi 5 kelompok belajar untuk mengerjakan lembar kerja siswa secara berkelompok. Data kemampuan kognitif siswa yang selama proses pembelajaran menerapkan model pembelajaran SIMAS ERIC (Skimming, Mind mapping, Questioning, Exploring, Writing, Communicating. Pencapaian hasil yang diperoleh siswa dalam pengerjaan LKS rata-rata $85,70 \%$ sehingga dapat dikatakan ketuntasan belajar siswa sudah tercapai. Kualifikasi pencapaian aspek kognitif siswa pada LKS terlihat pada tabel di bawah ini.

\section{Tabel 2. Kualifikasi Pencapaian Kognitif Siswa}

\begin{tabular}{cccc}
\hline Interval & Frekuensi & $(\%)$ & Kualifikasi \\
\hline$\geq 75$ & 25 & 100 & Tuntas \\
$\leq 75$ & - & - & - \\
Jumlah & 25 & 100 & - \\
\hline
\end{tabular}

\section{Data Kemampuan Afektif Siswa}

Penilaian aspek afektif menggunakan lembar observasi yang disediakan oleh peneliti mencakup 7 aspek penilaian yaitu, di kelas (hadir di kelas di beri nilai 1 dan absen diberi nilai), kelengkapan buku referensi, mencari informasi dan buku referensi dan LKS, partisipasi aktif dalam kelompok, bertanya atau menyampaikan argumentasi dalam diskusi, menghargai pendapat teman dan memberikan solusi.

Penilaian afektif atau sikap siswa dilakukan selama kegiatan proses pembelajaran berlangsung. Data penilaian pada aspek afektif terlihat pada tabel dibawah ini.

Tabel 3. Kualifikasi Pencapaian Siswa Pada Aspek Afektif

\begin{tabular}{cccc}
\hline Interval & Frekuensi & $(\%)$ & Kualifikasi \\
\hline$\geq 75$ & 25 & 100 & Tuntas \\
$\leq 75$ & - & - & - \\
Jumlah & 25 & 100 & - \\
\hline
\end{tabular}

Dari tabel di atas, hasil pencapaian pada aspek afektif terlihat pada interval $\geq$ 75 sebanyak 25 siswa (100\%) mendapatkan nilai yang baik dengan kualifikasi tuntas dan pada interval $\leq 75$ tidak terdapat siswa dengan kualifikasi gagal dengan presentasi rata-rata yang diperoleh siswa adalah $87,41 \%$, jika dibandingkan antara nilai KKM sekolah 75 maka dapat dikatakan pencapaian siswa berada pada kualifikasi tuntas.

\section{Data kemampuan psikomotor siswa}

Penilaian aspek psikomotor menggunakan lembar observasi yang disediakan oleh peneliti mencakup 4 aspek penilaian yaitu, melakukan langkah-langkah pada LKS, ketelitian hasil percobaan, menyimpulkan hasil kerja dan mempresentasikan hasil kerja kelompok. Penilaian psikomotor atau keterampilan siswa dilakukan selama kegiatan proses pembelajaran berlangsung. Data penilaian pada aspek psikomotor terlihat pada tabel berikut.

Tabel 4. Kualifikasi Pencapaian Siswa Pada Aspek Psikomotor

\begin{tabular}{cccc}
\hline Interval & Frekuensi & $(\%)$ & Kualifikasi \\
\hline$\geq 75$ & 25 & 100 & Tuntas \\
$\leq 75$ & - & - & - \\
Jumlah & 25 & 100 & - \\
\hline
\end{tabular}

Hasil penelitian yang terlihat pada tabel di atas menunjukkan bahwa pada interval $\geq$ 75 sebanyak 25 siswa (100\%) mendapatkan nilai dengan kualifikasi tuntas dan pada interval $\leq 75$ tidak terdapat siswa dengan kualifikasi gagal. Presentasi ratarata yang diperoleh siswa adalah $90,56 \%$, jika dibandingkan antara nilai KKM sekolah 75 maka dapat dikatakan pencapaian siswa berada pada kualifikasi tuntas.

\section{3) Deskripsi data kemampuan hasil tes formatif (tes akhir) siswa}

Tes akhir (tes formatif) dilakukan pada akhir pertemuan. Tes akhir dilakukan dengan tujuan untuk mengetahui tingkat penguasaan siswa pada konsep sistem pernapasan pada manusia dengan menerapkan model pembelajaran SIMAS ERIC (Skimming, Mind mapping, 
Questioning, Exploring, Writing, Communicating), maka kualifikasi presentase pencapaian hasil tes akhir (tes formatif) siswa terlihat pada tabel berikut.

Tabel 5. Kualifikasi Tingkat Penguasan Siswa Pada Tes Akhir (Tes Formatif)

\begin{tabular}{cccc}
\hline Interval & Frekuensi & $(\%)$ & Kualifikasi \\
\hline$\geq 75$ & 25 & 100 & Tuntas \\
$\leq 75$ & - & - & - \\
Jumlah & 25 & 100 & - \\
\hline
\end{tabular}

Dari hasil penelitian yang tertera pada tabel di atas, menunjukkan bahwa pada interval $\geq 75$ sebanyak 25 orang siswa dapat berhasil memperoleh nilai yang baik dengan kualifikasi tuntas dan pada interval $\leq 75$ tidak terdapat siswa dengan kualifikasi gagal. Presentasi rata-rata yang diperoleh siswa adalah $87 \%$ jika dibandingkan antara nilai KKM sekolah 75 maka dapat dikatakan pencapaian siswa berada pada kualifikasi tuntas.

\section{4) Deskripsi Nilai Akhir (NA) Yang Diperoleh Siswa}

Nilai akhir yang merupakan hasil belajar siswa dapat diketahui dari presentase tingkat penguasaan siswa pada nilai proses (aspek kognitif,afektif, dan psikomotor) dan presentase penguasaan siswa pada hasil tes akhir (tes formatif). Tingkat penguasaan setiap siswa berbedabeda, ini terlihat dari hasil nilai akhir yang bervariasi. Data kualifikasi pencapaian siswa pada nilai akhir terlihat pada tabel di bawah ini.

Tabel 6. Kualifikasi Pencapaian Siswa Pada Nilai Akhir

\begin{tabular}{cccc}
\hline Interval & Frekuensi & $\mathbf{( \% )}$ & Kualifikasi \\
\hline$\geq 75$ & 25 & 100 & Tuntas \\
$\leq 75$ & - & - & - \\
Jumlah & 25 & 100 & - \\
\hline
\end{tabular}

\section{b. Pembahasan}

Hasil penelitian pada tabel di atas menunjukan bahwa pada interval $\geq 75$ sebanyak 25 siswa memperoleh nilai dengan kualifikasi tuntas sedangkan pada interval $\leq 75$ tidak terdapat siswa dengan kualifikasi gagal. Presentasi rata-rata yang diperoleh siswa adalah $85,23 \%$.

\section{5) Hasil Belajar Pada Aspek Kognitif}

Sebelum melakukan kegiatan belajar mengajar (KBM) siswa diberikan tes awal (pre test) tabel 1 terlihat hasil pencapaian siswa pada tes awal, dimana pada interval $\leq 75$ terdapat 25 siswa (100\%) berada pada kualifikasi kurang dengan rata-rata skor pencapaian 39,6\%. Nilai rata-rata pencapaian pada tes awal yaitu 36,6\% dengan nilai yang dicapai dapat disimpulkan bahwa siswa belum mencapai indikator pada konsep sistem pernapasan pada manusia. Hal ini dapat dimaklumi karena sebagian besar siswa belum memiliki pengetahuan dasar mengenai materi yang diajarkan sehingga hasil belajar yang dicapai menjadi rendah.

Setelah peneliti melakukan proses pembelajaran menggunakan model pembelajaran SIMAS ERIC (Skimming, Mind mapping, Questioning, Exploring, Writing, Communicating) hasil tes akhir siswa menunjukan perbedaan yang signifikan. Dari hasil penelitian, hasil tes akhir menggambarkan bahwa terdapat 25 siswa (100\%) mampu mencapai nilai yang baik dengan kualifikasi tuntas. Nilai ratarata yang dicapai pada tes akhir yaitu $87 \%$ Dengan demikian dapat disimpulkan bahwa siswa telah mencapai ketuntasan belajar pada konsep sistem pernapasan pada manusia. Hal ini dikarenakan siswa dapat terlibat aktif dalam proses pemecahan masalah dan mengerjakan tugas yang diberikan dengan penuh tanggung jawab.

Pada aspek kognitif ini juga, siswa mengerjakan Lembar Kerja Siswa (LKS) secara berkelompok dimana siswa dibagi menjadi 5 kelompok dengan masing-masing kelompok berjumlah 5 siswa. Dengan bekerja secara berkelompok menunjukkan bahwa siswa mampu memecahkan dan menyelesaikan setiap masalah yang terdapat dalam Lembar Kerja Siswa (LKS) pada setiap pertemuan. Berdasarkan pada tabel 2, presentase pencapaian siswa pada aspek kognitif berada pada kualifikasi baik.

Model pembelajaran SIMAS ERIC (Skimming, Mind mapping, Questioning, Exploring, Writing, Communicating) adalah model pembelajaran yang melibatkan siswa untuk memecahkan suatu masalah dengan 
membuat peta konsep dan menjawab pertanyaan dari setiap masalah yang telah di tentukan pada setiap indikator pembelajaran (Danial, 2010). Masalah yang digunakan sebagai fokus pembelajaran dapat diselesaikan siswa melalui kerja kelompok sehingga dapat memberi pengalaman-pengalaman belajar yang beragam pada siswa. Model pembelajaran SIMAS ERIC (Skimming, Mind mapping, Questioning, Exploring, Writing, Communicating) dapat meningkatkan pemahaman siswa tentang apa yang mereka pelajari sehingga diharapkan mereka dapat menerapkannya dalam kondisi nyata dalam kehidupan sehari-hari (Dasna, 2007).

Bila pembelajaran yang dimulai dengan suatu masalah, apalagi kalau masalah tersebut bersifat kontekstual, maka dapat terjadi ketidakseimbangan kognitif pada diri siswa. Keadaan ini dapat mendorong rasa ingin tahu sehingga memunculkan bermacam-macam pertanyaan di sekitar masalah (Dasna, 2007). Masalah-masalah yang muncul dapat berasal dari guru maupun siswa, baik dalam bentuk bacaan maupun pertanyaan. Pertanyaan yang berasal dari siswa dapat dikategorikan berdasarkan jenis dan struktur pertanyaan yang disusun. Hal ini dapat menggambarkan tingkat kognitif siswa yang meliputi C1 (pemahaman), C2 (memahami), C3 (menerapkan) dan C4 (menganalisis).

Model pembelajaran SIMAS ERIC (Skimming, Mind mapping, Questioning, Exploring, Writing, Communicating) menunjukan bahwa sintaks-sintaksnya dapat membantu meningkatkan hasil belajar kognitif siswa. Pada sintaks SIMAS ERIC (Skimming, Mind mapping, Questioning, Exploring, Writing, Communicating) tahap membuat peta konsep dan menyusun pertanyaan dapat merangsang perkembangan kognitif siswa. Kegiatan membuat peta konsep merupakan tahap untuk mengidentifikasi dan mengolah informasi yang diperoleh, kemudian dituliskan oleh siswa sebagai rangkuman dari pengetahuan dan konsep-konsep yang dipahaminya.

\section{6) Hasil Belajar Pada Aspek Afektif}

Penilaian pada aspek afektif berkaitan dengan sikap siswa selama proses pembelajaran. Berdasarkan pada tabel 3, menunjukan bahwa sebanyak 25 siswa $(100 \%)$ mampu mencapai hasil yang baik dengan skor rata-rata yaitu $87,41 \%$. Ketuntasan hasil belajar afektif pada siswa dikarenakan terciptanya suasana yang dapat membangkitkan semangat belajar siswa dan siswa merasa termotivasi untuk memecahkan setiap masalah yang diberikan. Hal ini menunjukkan bahwa dengan diterapkannya model pembelajaran SIMAS ERIC (Skimming, Mind mapping, Questioning, Exploring, Writing, Communicating) sangat membantu siswa dalam mencapai ketuntasan hasil belajar pada aspek afektif.

\section{7) Hasil Belajar Pada Aspek Psikomotor}

Menurut Hamdani (2010), ranah psikomotor berhubungan dengan selukbeluk yang terjadi karena adanya otot-otot oleh pikiran sehingga diperoleh keterampilan fisik tertentu. Aspek psikomotor mencakup keterampilan siswa yang berlangsung selama proses pembelajaran. Berdasarkan tabel 4, menunjukkan bahwa skor rata-rata pada aspek psikomotor yaitu 90,56\%. Berdasarkan jumlah nilai rata-rata pada aspek psikomotor dapat dinyatakan bahwa siswa tergolong dalam kualifikasi tuntas. Keberhasilan ini diperoleh karena siswa serius dan bertanggung jawab dalam memecahkan setiap masalah yang diberikan.

\section{8) Nilai Akhir}

Nilai akhir dapat berupa angka maupun huruf yang melambangkan keberhasilan siswa. Nilai akhir diperoleh dari nilai proses yaitu, nilai kognitif Lembar Kerja Siswa (LKS), afektif, psikomotor dan nilai tes akhir. Hasil nilai akhir tersebut dapat dinyatakan sebagai berikut, 25 siswa berhasil dengan kualifikasi tuntas dengan nilai rata-rata 85,23\%. Hasil penelitian menunjukan bahwa dengan menerapkan model pembelajaran SIMAS ERIC (Skimming, Mind mapping, Questioning, Exploring, Writing, Communicating) dapat memberikan pengaruh yang baik terhadap hasil belajar siswa. Dengan menerapkan model pembelajaran ini, siswa dapat terlibat secara aktif dalam setiap proses 
pembelajaran, siswa dapat berpikir kritis untuk memecahkan setiap masalah yang diberikan dan siswa juga dapat memperoleh informasi dari berbagai sumber, sumber yang di maksud yaitu, dari kelompok lain serta lebih berani dalam mengemukakan pendapat mereka mengenai materi yang dipelajari.

Pembelajaran dengan model SIMAS ERIC (Skimming, Mind mapping, Questioning, Exploring, Writing, and Communicating) menekankan aktivitas siswa lebih banyak dibandingkan guru melalui pembelajaran antar kelompok dengan pemberian masalah yang berkaitan dengan kehidupan sehari-hari, membuat peta konsep, menyusun pertanyaan dan menjawab pertanyaan yang telah di buat. Selain itu pembelajaran dengan model SIMAS ERIC (Skimming, Mind mapping, Questioning, Exploring, Writing, and Communicating) siswa dapat saling berbagi pengetahuan dan berusaha menggali informasi secara mandiri serta siswa dipandang sebagai subjek belajar sedangkan guru hanya bertindak sebagai fasilitator dan motivator. Penerapan model pembelajaran SIMAS ERIC (Skimming, Mind mapping, Questioning, Exploring, Writing, and Communicating) dapat membuat siswa mencapai kriteria ketuntasan minimal (KKM) atau dengan kata lain penerapan model pembelajaran SIMAS ERIC (Skimming, Mind mapping, Questioning, Exploring, Writing, and Communicating) dapat meningkatkan hasil belajar siswa pada konsep sistem pernapasan pada manusia.

\section{SIMPULAN}

Berdasarkan hasil penelitian dan pembahasan, maka dapat disimpulkan bahwa, ada peningkatan hasil belajar siswa dintunjukan lewat hasil tes formatif setelah diajarkan materi sistem pernapasan pada manuisa dengan penerapan model pembelajaran SIMAS ERIC (Skimming, Mind mapping, Questioning, Exploring, Writing, Communicating)

\section{DAFTAR PUSTAKA}

Arikunto. 2005. Dasar-Dasar Evaluasi Pendidikan, Jakarta, Bumi Aksara

Corebima. 2009. Pengalaman berupaya menjadi guru professional. Malang: Universitas Negeri Malang.

Danial, 2010. Pengaruh strategi pembelajaran PBL dan Gl terhadap metakognisi dan penguasaan konsep kimia dasar. Malang: Universitas Hegeri Malang.

Darmawan, Davies, \& Hadi. 2014. Penyempurnaan Integrasi Model Pembelajaran Simas Eric dan Blended learning terhadap Hasil Belajar. Malang: UniversitasNegeri Malang, Prosiding Seminar dan Workshop Nasional Biologi/IPA dan Pembelajarannya.

Dasna, I. W. 2007. Pembelajaran Bebasis Masalah. Bandung: Bumi Aksara

Hamdani. 2010. Penilaian Hasil Proses Belajar Mengajar. PT Remaja Posdakarya Offset: Bandung.

Sudjana, N. 2010. Dasar-dasar Proses Belajar. Sinar Baru: Bandung.

Paramitha. 2011. Peta konsep atau mindmapping. Universitas Negeri Jakarta: Jakarta.

Suprijono. $2011 . \quad$ Model-Model Pembelajaran. Jakarta: Gramedia Pustaka Jaya.

Sudjoko. 2001. Petunjuk Kegiatan Pembelajaran Mikro. FMIPA UNY : Yogyakarta. 